\title{
All ages
}

INSERM

\section{Source}

INSERM. (1999). Orphanet: an online rare disease and orphan drug data base. all ages. ORPHA:409950

From birth to adulthood without peak of onset. 